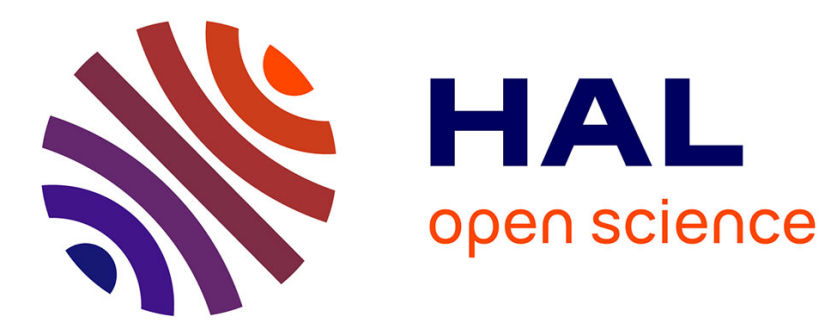

\title{
Emotions, narratives, and the art of making meanings: Nantes' memorial to the abolition of slavery
}

\author{
Renaud Hourcade
}

\section{To cite this version:}

Renaud Hourcade. Emotions, narratives, and the art of making meanings: Nantes' memorial to the abolition of slavery. Critical Policy Studies, 2020, 10.1080/19460171.2020.1818110 . hal-02958669

\section{HAL Id: hal-02958669 \\ https://hal.science/hal-02958669}

Submitted on 18 Nov 2020

HAL is a multi-disciplinary open access archive for the deposit and dissemination of scientific research documents, whether they are published or not. The documents may come from teaching and research institutions in France or abroad, or from public or private research centers.
L'archive ouverte pluridisciplinaire HAL, est destinée au dépôt et à la diffusion de documents scientifiques de niveau recherche, publiés ou non, émanant des établissements d'enseignement et de recherche français ou étrangers, des laboratoires publics ou privés. 


\title{
Emotions, narratives, and the art of making meanings:
}

Nantes' memorial to the abolition of slavery

\author{
Renaud Hourcade \\ Univ Rennes, CNRS, ARENES - UMR 6051, Rennes, France
}

Pre-print version

For citation please refer to the published article : Renaud Hourcade, "Emotions, narratives, and the art of making meanings: Nantes' memorial to the abolition of slavery", Critical Policy Studies, 2020, https://doi.org/10.1080/19460171.2020.1818110

\begin{abstract}
This paper discusses the role and use of emotion in public policy. Approaching emotions from the standpoint of narrative analysis, it offers a detailed account of the way emotions were storied and enrolled in a specific local policy process: the construction of a memorial to the abolition of slavery between 1998 and 2012 in Nantes, France, a former slave trade port. The article finds evidence that emotions are a powerful instrument for framing problems and solutions and making sense of a new policy instrument.It also argues that the ability of policy actors to enroll emotions in meaning-making operations is structured by dominant policy beliefs and constrained by power relations
\end{abstract}

\section{KEYWORDS}

Interpretive studies; memory politics; ethics; race relations; local policies; architecture 
Despite growing interest in recent research, emotions generally continue to be perceived as a secondary aspect of public policy processes. While scholars studying vote behavior (Marcus 2002; Neuman et al. 2007), political communication (Edelman 1971; Edelman 1977; Ballet 2014; Le Bart 2018) and social movements (Goodwin, Jasper, and Polletta 2001; Jasper 2011; Traïni 2009) have all highlighted the crucial influence of emotions on the political field, public policy researchers have remained, at best, moderately interested in the topic. A few remarkable exceptions set aside, public policy studies rarely point to emotions as prominent factors of the design, orientation, implementation, success or failure of policy schemes and instruments. Visions inherited from Weber of the ideal civil servant acting "sine ira et studio", i.e. "without hate nor passion" (Weber 1971, 231) and, more generally, the influence of rationalism on public policy studies may account for this lack of attention. An additional reason could be the epistemological reticence of many social science researchers to step into an area that could easily blur the border with psychological science (Braud 1996).

Yet, recent scholarship has identified a series of policy fields in which individual and collective affects undoubtedly play a role. This has been made evident for instance in the fields of care policy (Durnová 2013), public safety (Richards 2007; Burlone and Mévellec 2019), international relations (Mercer 2010), health policy (Paterson 2019), medical research (Gottweis 2012), and participation forums (Barnes 2008; Blondiaux and Traïni 2018), among others. Drawing on these studies, emotions can be seen as influential in various ways: policy actors, from top politicians to street-level bureaucrats, may seek guidance from their own personal emotions (Anderson 2016), interpret a situation through emotion-ridden media accounts (see Henry 2015 about asbestos, Burlone and Mévellec about killer dogs), or face a public whose (unanticipated) emotional attitudes jeopardize the effectiveness of policy instruments based on rational choice assumptions 
(Van Oorschot, Fenger, and Van Twist 2016; Durnová and Hejzlarová 2018). Even policy expertise is not immune to emotions, as is scientific work in general (Pickersgill 2012; Durnová 2019). All of these studies have strongly argued against the often-alleged disconnection between affects, beliefs and rationality. Rather, they hold that "emotional display and the language of passion may very well coexist with argumentative and ethical discourse" (Gottweis 2012). Such a perspective is congruent with recent works in philosophy (Nussbaum 2001), anthropology (Beatty 2014) and neuroscience (Garcés and Finkel 2019), which now leave little doubt that "emotion is part of reasoning and not a distraction upsetting a coldly rational process" (Mercer 2010, 5).

These and many other works in the broad field of social theory have insisted that emotions structure social life, but also, importantly, that social and political life structures emotions. Rather than as spontaneous psychological states, affects have to be seen as cultural and social practices which directly contribute to processes of domination and subordination (see for instance Elias 2000; Ahmed 2014). Since public policies are a social practice, they can contribute to shape legitimate emotions. This is an additional reason why they should not be overlooked in policy studies.

Yet, from a public policy perspective, what exactly should be called "emotions" and how exactly they influence public policymaking remain a matter of interrogation. Should scholars interested in the topic focus on embodied emotions, which immediately raises the issue of how to map and measure psycho-physiological transformations with the (limited) help of the social sciences' methodological toolbox? Or should they give more centrality to narrated emotions, in a way that would rather approach them through their discursive nature and rhetorical power ? Although this is certainly not the only way to proceed (see Anderson 2014 for an approach based on the observation of micro- 
interactions) and despite the fact that emotions have actually "not been given any special analytical emphasis in interpretive works" (Durnová and Hejzlarová 2018, 412), I argue that approaching emotions from the standpoint of discourse and narrative analysis (Roe 1994; Stone 2012; Fischer and Forester 1993; Jones, Shanahan, and McBeth 2014) is an accessible and productive way to better understand their role in the policy process.

This paper aims at assessing the discursive role of emotions in a particular policy process, i.e. the local public policy that resulted in the building of a large memorial to the abolition of slavery in Nantes, a former slave trade port on France's Atlantic coast. During the slave-trade era, Nantes was the country's main departure port for maritime expeditions to Africa and the Americas, an activity that enriched local merchants and developed the city's economy until the ban of the slave trade at the beginning of the $19^{\text {th }}$ century. In 1998, city leaders decided to build a memorial to slavery, the first of its kind in Europe. This move followed decades of reluctance to officially acknowledge the role of the city in the slave trade, let alone commemorate it. To what extent did emotional narratives contribute to framing Nantes' uncomfortable memory as a public problem? What role did emotions play in the framing activities that sought to "make sense" of the memorial?

According to Rein and Schön $(1993,146)$ framing is "a way of selecting, organizing, interpreting, and making sense of a complex reality to provide guideposts for knowing, analyzing, persuading, and acting". Framing Nantes' memory problem involved a sustained use of emotion-ridden narratives. Later, having the memorial built and, even more importantly, setting its symbolic and political meaning, also involved multivocal rhetorical efforts based on emotions. This article argues that for Nantes' officials, governing the local public memory process amounted to deciding on which emotions, which narratives and which related meanings were allowed to be part of it, and which 
were not. Establishing this boundary involved storytelling struggles waged by various sense-makers, i.e. memory activists, politicians, and, importantly, the artist. The article also shows that this discursive process of legitimizing/delegitimizing emotions was deeply intertwined with the expression of broader policy beliefs and values. When emotions were deemed to be congruent with the dominant ethical framework, they were welcomed and valued. Those that were not deemed congruent, or were even seen as subversive, were discursively combatted by the political actors in charge of justifying policy. I call this observed correlation between the sort of affects displayed and the expression of specific political values an ethics-emotion nexus.

The first section of the article discusses some of the literature in the broad field of political studies with the view to highlighting key dimensions of the interplay between emotions, narratives and meaning-making. In the three other sections, I present the case of Nantes in more detail. The second section focuses on the role of narrated emotions in the framing of Nantes' memory problem and the decision to build a memorial. The third section analyzes the architectural language of the memorial and explains why it was discursively contested. The last section shows how politicians in Nantes have striven to keep control of the memorial's meanings in the context of a public policy with multiple voices. It argues that the discursive struggles waged on that occasion were structured by two competing ethics-emotions nexuses: a "duty to remember" trope and an "anti-repentance" trope. Research material is drawn from in-depth ethnographic fieldwork (2007-2012) carried out as part of a doctoral thesis, combining interviews with concerned parties, politicians, experts and civil servants, field observations and an extensive press review.

\section{The "storied nature of emotions"}

As Braud observes $(1996,8)$, affects "are at the heart of the formation of interests and 
aspiration" and they "give to collective conflicts and sociability their fundamental dynamics". But while their influence on the political field has been "obvious to the least inattentive observer", many theorizations of political processes have actually glossed over emotions. To be sure, this lack of attention has not been specific to the field of political studies. For a long time, in most social sciences, emotions have been "either scorned or obscurely acknowledged as fundamental", notes anthropologist Andrew Beatty (2014, 546) - in other words the scientific equivalent of an elephant in the room. The sway of

Durkheimian structuralism, which inclined to categorize emotions as inconsequential human idiosyncrasies - "actually, impulses and emotions explain nothing: they are always results, either of the power of the body or of the impotence of the mind" once wrote Levi-Strauss (Levi-Strauss 1962, 71 quoted in Beatty 2014: 548) - and later the reduction of individual behavior to interest-focused calculation, largely accounted for this negligence. For the last thirty years, however, emotion-centered works have blossomed across the social sciences providing compelling insights into the pervasiveness of affects in the social world.

\section{Emotions in political studies}

Political studies now hardly leave any doubt that emotions heavily contribute to the formation of political opinions (Marcus 2002; Brader, Marcus, and Miller 2011; Vasilopoulos et al. 2019) and that the "art of persuasion" relies as much on emotion as on good arguments (Gottweis 2012; Ballet 2014). "Moral shocks" - "a visceral, bodily feeling, on a par with vertigo or nausea (...) prompted by unexpected event or piece of information" (Goodwin, Jasper, and Polletta 2001, 16) fuel participation in protests. Mobilized groups create settings and performances that act as "sensitization devices" (Traïni 2009), using emotions to foster adhesion to their cause. Activists work hard to 
elicit moral outrage, shame, disgust... and, importantly, make them resonate with specific concerns and values. Protesters, as Jasper observes, "self-consciously use emotion displays to coordinate action, to attract and retain participants, and to pressure other strategic players with whom they interact" (Jasper 2014, 208). Anger and indignation in particular foster engagement : "they not only motivate participation but they direct blame for social problems, create sympathy for protestors, and guide strategic choices" (Jasper 2014, 209. See also Ost 2004). In the context of demonstrations, marches and electoral meetings, the elation of the crowd (thrill, solidarity, excitement, etc.) provides a remarkable source of energy and a motivation for recurring participation. On the other hand, contrary to the common perception of political decision-makers as cold-headed rationalists (Ost 2004), studies have exposed the influence of emotions on politicians, as well as their capacity to use emotional rhetoric to reach their goals, a feature of human politics with probably the longest history of academic scrutiny (considering Plato and Aristotle's reflections about the tryptic pathos/ethos/logos in politics - Cordell 2017). Today's electoral campaigns, with their spin-doctored scenography and mass media amplification, offer a sophisticated setting for the language of persuasion that sits at the heart of politics (Ballet 2014).

With such a wealth of emotion-focused works published in the last decades, Goodwin, Jasper and Poletta's observation, made twenty years ago, that "somehow academic observers have managed to ignore the swirl of passions all around them in political life" (Goodwin, Jasper, and Polletta 2001, 1) may no longer hold true. What can be affirmed, however, is that public policy studies collectively lagged behind most other subfields of political science when the invitation came up to take the "emotional turn". Why would public policy processes be more immune to emotions than collective mobilization or electoral competition? They are not, but mainstream public policy research has been slow 
to thoroughly acknowledge, track and measure the role of passions.

This does not mean that affects have been overlooked altogether. In fact, some strong, albeit patchy, foundations had been laid for long. Rational choice theorists, for instance, portray emotions as one important factor explaining bounded rationality (Simon 1983), although they have rarely explored this dimensions deeply (Muramatsu and Hanoch 2005). Regarding policy making, the construction of target populations, as it is described by Schneider and Igram (1993) for instance, involves taking into account hierarchies of social standing, reputation, and moral judgements, which departs from strictly rational choice mechanisms. Joseph Gusfield (1963) also famously analyzed the crucial symbolic dimensions of public policy claims regarding temperance movements. As soon as it was understood that policies, whether unintentionally or on purpose, could speak to feelings of belonging, contribute to social hierarchies, strengthen stigma and shame, or enhance collective pride (Lamont 2018), a connection between policymaking and collective emotions was established. The stream of works dating back to 1970 that made evident the social construction of public problems and the subtilities of agenda-setting were another field concerned with emotions. Highlighting the role of the media in the framing of social problems, Cohen, for instance, noted their capacity to elicit strong emotional reactions from the public and politicians, a process he famously designed as "moral panics" (Cohen 2002 [1972]). Despite the great merits of these early works, however, it is mainly in the wake of the "linguistic turn" of the early 1980s that scholars started to explore more comprehensively the connections between emotions, discursive framing, and the policy process. 


\section{Narratives, emotions and meaning-making}

The interpretive tradition which has emerged as an offshoot of the "argumentative turn" (Fischer and Forester 1993) in public policy studies emphasizes the role and power of discourse in political action (Roe 1994; Fischer 2003; Durnová, Fischer, and Zittoun 2016). According to scholars in this field, policy design, instruments and goals largely result from discursive activities that classify actors, problems, values and events. In accordance with the phenomenological tradition in philosophy and social theory, language is not seen as a mere vehicle to convey meanings, nor "simply a mirror or picture of the world". Rather, it "profoundly shapes our view of it in the first place" (Fischer and Forester 1993, 1). It results that policy goals, policy knowledge and values do not have a proper, objective reality outside language: they are co-produced by discourses (Yanow 1996; Wagenaar 2011). It also results that problems are rhetorically constructed before they are solved. In other words, the symbolism of language deeply matters for political practice and power relations.

Seen from this theoretical standpoint, narratives and stories appear as a crucial way to construe policy meanings (Roe 1994; Stone 2012; Jones, Shanahan, and McBeth 2014) ${ }^{1}$. As Fischer $(2003,162)$ states: "it is through the act of storytelling that individuals assess

\footnotetext{
${ }^{1}$ Although some authors deem useful to conceptually differentiate narratives from stories, I take the view in this paper that the two notions refer to the same phenomenon, i.e. "a cognitive process that organizes human experiences into temporally meaningful episodes", as Polkinghorne $(1988,7)$ defines it. According to this author, examples of narratives "include personal and social histories, myths, fairy tales" as well as "the everyday stories we use to explain our own and others' actions". Many works in the broad social sciences field also use the words "story" and "narrative" indifferently (see for instance Rein and Schön 1993; Polletta 2006 ; Jones, Shanahan, and McBeth 2014).
} 
their social positions in their respective communities, grasp the goals and values of their social groups and communities, internalize their social conventions, and understand who they are vis-a-vis one another". A process of "discourse institutionalization" takes place, according to Hajer (1993), "when the narrative or story line of a discourse comes to dominate a society's conventional ways of reasoning and the practices of its dominant social and political institutions" (Fischer and Forester, 9). Building a narrative "brings elements of meaning, clarity, stability, and order into what usually tends to be the complicated and contradictory world of politics" (Gottweis 2012, 221). That makes stories "essential for the shaping of policies, the settling of conflicts, and the securing of legitimacy for political action" (Gottweis 2012, 221).

As this paper intends to show, emotions can be a crucial component of this discursive performativity. Emotions, as Ahmed recalls $(2014,13)$, involve speech acts and they are performative. For instance, she writes, 'the sentence 'the nation mourns' generates the nation as if it were a mourning subject". In the same way, collective shock, shame, pity, compassion or anger are affective "states" that are not spontaneously "felt" by individuals, but rather constructed through discourses, including through public policy narratives. Indeed many emotions - especially those with a politically relevant moral content like disgust and shame (Nussbaum 2006), anger (Ost 2004) or indignation (Ambroise-Rendu and Delporte 2008) - rely on a complex cognitive structure, involving the construction of a plotted story with a setting, a plot, characters (heroes, villains, victims), and a moral or a way forward. This is what Kleres terms the "storied nature of emotions" (Kleres 2011, 185), insisting on their temporal, sequential dimension. Fear for the future is a feeling that is intellectually much more elaborated than the spontaneous, Darwinian fear one can feel when facing a barking dog. Anger against political "villains" 
is not exactly anger directed toward the robber of your bicycle. Indignation is a complex ethical construction evolving notions of justice and dignity. Mobilizing such emotions at a collective level can bring legitimacy, justification and consent to policy choices. But their effects may depend on "past histories" (Ahmed 2014, 13) or what Beatty calls "a contextual interpretation drawing from deeper currents, stories within stories" (Beatty 2014, 558). In the following section, I will propose a detailed analysis of the Nantes' memorial case study with the view to highlighting the way this kind of emotional narrative has been instrumental in the construction of the local slavery memory as a problem deserving public interest.

\section{Symbolic damage and the framing of public memory in Nantes}

\section{A broken statue}

In 1998, France celebrated the 150th anniversary of the abolition of slavery. Commemoration events and exhibitions were organized across the nation. In Nantes, the country's main slave-trading port, a local group of memory advocates, many of them Caribbean people of African descent, seized the opportunity to set up a special commemorative operation. On the anniversary of the Emancipation Act (April 27), they

unveiled a statue they had commissioned from a young local artist. Made of iron and cement, the sculpture stood on the Quai de la Fosse, a wharf on the Loire River where slave trade ships used to be moored. It portrayed a free slave raising her arms, looking up to the sky, with broken chains dangling from her wrists. The artwork was presented as a temporary symbol: members of the advocacy group wanted the statue to remain on the quay until it was replaced by a permanent, official, memorial. Up until then, city councilors had firmly rejected the request: a few years before, Nantes had organized a 
temporary exhibition about slavery called "The Shackles of Memory", the first ever public event to deal with this matter in Nantes, and even in the country (Hourcade 2017). Although the exhibition had been closed for several years at the time, in the view of the local authorities, no further action was required.

On the day of the commemoration, the monument was unveiled before a large, sympathetic crowd. Yet, during one of the following nights, the statue was knocked down. One arm was severed from the body and thrown into the river. The chains were wound around one ankle, as if the character had been trussed up. Although the authors of the damage and their intentions were unknown, the act was interpreted by memory activists as a provocation intended to "dishonor the slaves"2. They readily framed the event as a moral scandal and spoke of their "shock" and "indignation". The local press contributed to build a supportive, emotional story-telling of the event. Shortly after the announcement of the damage caused to the statue, articles related "the very positive messages of solidarity" received by the activist group ${ }^{3}$, mentioning that the entire Nantes population felt the same "shock" as they $\mathrm{did}^{4}$. Politicians, on their side, deemed the act "unspeakable", "an insult to the slaves' memory" and "a shame and disgust for all democrats"7. Memory advocates strategically maintained this emotional climax by

2 "Les nantais choqués par le saccage de la statue en mémoire de l'esclavage", Presse Océan, May 4, 1998

3 "Esclavage: un symbole fracassé", Ouest France, May 4, 1998

4 "Les nantais choqués par le saccage de la statue en mémoire de l'esclavage", Presse Océan, May 4, 1998.

5 “Statue saccagée quai de la Fosse: 'Un geste inqualifiable' pour Jean-Marc Ayrault", Ouest France, May 7, 1998

6 "Fosse: sculpture monumentale en projet", Ouest France, May 5, 1998.

${ }^{7}$ Press release by the Socialist Party, quoted in Dom Tom Com, nº25, 2nd quarter 1998: 8. 
leaving the destroyed statue lying on the spot for three weeks, and gathering for a silent ceremony around the collapsed concrete body. When the statue was finally withdrawn, they also put a sign on the spot asking passers-by to "recall the ignominy" of what happened on that site.

Dramatized anger and indignation are not rare in the strategic repertoire of mobilized groups. As Jasper writes, "protestors must create and sustain a sense of moral obligation and justice". Moral shocks are useful in this perspective, since they "signal that the world is not as it seemed, thereby demanding attention and revaluation" (Jasper 2014, 210). The "desecration" of the statue was perceived as "an insult" to people of African descent, but it also made Nantes' ambiguous, unsolved relationship to the slave trade all the more evident. This narrative had a logical conclusion: it was urgent to build the official, cityfunded, memorial the memory advocates had long called for. A political tragedy was thus discursively put together in the form of a plotted story, with its setting, characters, moral, and way forward (Jones, Shanahan, and McBeth 2014, 5). This strategy worked well. Shortly after the event, a member of the city council announced that, as a response to this "barbaric act", public funding would be made available in order to build a permanent monument. The cost, at that time, was estimated at around 50,000 - 100,000 euros ${ }^{8}$. The construction was expected to be completed by 2000 .

\section{A damaged statute}

Policy narratives can take a stronger emotional dimension depending on how much they resonate with personal experiences. To understand fully why the damaging of the liberated slave was not merely seen as another damaged monument implies taking this

\footnotetext{
${ }^{8}$ It later reached 6 million euros.
} 
broader, moral and experiential background of the members of advocacy groups into account. Since the early 1980s, a group of Nantes Caribbean militants (with family origins mainly in Martinique and Guadeloupe) had set up various organizations and events aimed at exploring connections between creole identities, the history of slavery and the enduring effects of racism (Hourcade 2012). Their personal relationship to memory issues involves the feeling of not being fully respected as a group and as individuals because of enduring racial stigmatization. This has given their relationship to the city's slave-trading past a much more intimate and sensitive nature than for any other community. For instance, Isabelle, one member of the group, says that being involved in memory advocacy amounted to a "therapy" that helped her get rid of the "shame of being black". It also gives her a particular perception of the city's geography:

"When my brother came to visit me in Nantes for the first time, we strolled around the city together. When we arrived on the Quai de la Fosse, I told him 'Hey, we are on the Quai de la Fosse! This is where your colonizer ancestors left from to fetch your African ancestors to take them to Martinique!' He personally wouldn't accept that: 'Where do you see I have African ancestors?' he said!" 9

Her brother had not done the same "identity work" as she had, she explains. He probably would not have been moved by slave trade memory issues in the same way as her. This anecdote echoes Beatty's views on emotions (2014: 552): "primed by evolution, to be sure; shaped by culture; constrained by subject position; but given personal relevance and intensity by individual history". The experiential background of these militants is often expressed through personal narratives related to racism and the occultation of the slavery past. For instance, Serge tells the following story when asked why slavery memory policies matter to him:

\footnotetext{
${ }^{9}$ Interview with Isabelle, Nantes, 2008.
} 
"It's something that used to strike me when I was a child, when I saw the béké [the creole white class descending from plantation owners], how they spoke to people working in the banana fields. With very strong authority... workers would say 'yes sir', always bowing their heads. Once I saw an old man, and it shocked me how the owner, who was a béké, spoke to him, without respect, calling him an idiot, and the man had to bow low and answer 'yes sir'... (...) I was shocked. I asked my father, 'how can he accept that?', and my father said, 'Don't get involved, you kids, it's none of your business'. He never wanted to tell me about what was happening. (...) But when we were kids, and still today, we could see that domination."10

Another example is given by Jules, a founding member of the group, when recalling his feelings of shock and anger at his fellow Martiniquais' display of self-accepted inferiority:

"I was revolted by my parents. Because they were colonized people. My father, I used to see him, he was prepared to go into his orchard and pick the most beautiful fruits to give to the gendarmes when they passed by. And so they came every week to get food for nothing! He would do that with white people, yet he wouldn't have given a single orange to our neighbor, because he was black! I felt that revolt in me, I used to say to myself, you can't live like this... ${ }^{11}$ "

As noted earlier, emotions that are anchored in morality require a contextual interpretation which "draws from deeper currents" (Beatty 2014, 558). In this respect it is useful to note that the stories told by Serge and Jules are not only about emotions. They interweave feeling and thinking, suggesting that, at the personal level, cognitively construing ethics and meanings are not a fundamentally different mental process from experiencing emotions. Emotions are not opposed to reasoning: they rather "qualify as a special, highly developed, instance of the capacity to construe form, motive, backstory, personal relevance, and consequence" (Beatty 2014, 558).

Interestingly, although they don't share the same experiential backgrounds that Caribbean

\footnotetext{
${ }^{10}$ Interview with Serge, Nantes, January 2008

${ }^{11}$ Interview with Jules, Nantes, January 2009.
} 
militants, members of Nantes' white elite, among them politicians and journalists, also expressed emotion at the desecrated statue. Part of this emotion resulted from a feeling of solidarity with their fellow citizens. But to some extent, the destruction of the statue was also felt as an offense to their own identity and collective self-esteem. Indeed, for Nantes' leaders, this event shattered the comfortable storytelling they had managed to put together during the previous years, i.e. that the city had been capable of "facing up to the past" and paying due respect to Nantes people of Caribbean descent. This narrative was one of social consensus regarding history, minority recognition, and symbolic integration in the community. A sense of collective, local pride stemmed from this open attitude. This ethical background helps explain why the sobering spectacle of the destroyed statue structured the interpretation of the events by policy makers in a way that legitimized the building of an official monument. In the end, militants and policy actors narratives converged in a shared conclusion: the statue episode was a clear, shocking, indication of a public memory problem with slavery, a problem that a new memorial could solve.

\section{The “duty to remember" ethical trope}

With the announced construction of a new municipal memorial, local policy set off on a new track. It would be insufficient, however, to see narrated and dramatized emotions as the sole factor at play. Neither would it be fruitful to consider them in isolation from a broader ideological framework. In Nantes' case, change also occurred because, at the time of the policy decision, in Aristotelian terms, ethos was consistent with pathos. This favorable ethical pattern consisted in the rising influence, during the 1990s, of a moral imperative captured in a short formula: the "duty to remember" (in French: "devoir de mémoire"). By 1998, this expression had become a ubiquitous trope in the rhetoric of public memory advocates, favorable politicians and press articles (Hourcade, 2014). Notwithstanding its vagueness, or maybe thanks to it, this kind of ethical trope (Krieg- 
Planque 2010) offers a handy, readily accessible cognitive shortcut to decision makers to both conceive of and discursively justify their policies in the field of public memory.

The success of this formula was the result of a long-term change in beliefs associated with public memory. The evolution was linked to the growing recognition of the victims of state-sponsored crimes, particularly the Jewish victims of the Shoah, with which the French police of the Vichy regime was complicit, and to the parallel acknowledgement that, as a nation, facing up to the past could have more virtues, in terms of democracy and justice, than the policies of discretion, denial, or memorial obfuscation that were traditionally applied. This new attitude finally became a matter of national identity, as Ledoux underscores $(2012,119)$ :

"At the end of the 1990's, the 'duty to remember' constituted the hegemonical discourse of a new national posture - the commemoration of the victims of antisemitic persecutions - perceived by every politician (except at the far right), as the most radiant manifestation of their adhesion to the values of the Republic"

Alice Krieg-Planque (2010) argues that this kind of rhetorical trope produces meaning by binding together ethics and emotions: images of innocent victims, tacit references to mass crimes, and the necessity to restore (a part of) justice through memorialization are indeed encapsulated in the formula. Yet when applied to slavery or colonization, as was increasingly the case at the end of the 1990s when claims started to be voiced by French Blacks and descendants of Algerian migrants, the "duty to remember" formula incorporates an additional ethical dimension. It translates an offer of symbolic recognition made to racial minorities. This offer refers to their place in the national history, and to the moral necessity to praise their presence and include them in the collective narrative. This cognitive context most certainly had a strong moral and 
cognitive influence on Nantes city leaders' reaction to the statue event, and on their decision to build the memorial. This is illustrated by the way one of the key politicians in charge of the issue responded to questions about the meanings of this policy:

\footnotetext{
"We very much followed Aimé Césaire's thinking, particularly when he says that what matters most is the national narrative (roman national). Césaire always called for the Republic to accept, through its school curricula, through its republican ritual, this part of history, which is a part of our fellow French citizens. They will only be French when the Republic agrees to say 'yes, this is a part of our history, you are a part of our history, as much as French peasants are'."12
}

Building the municipal memorial is the logical conclusion of this story. As we shall see in the following section, however, governing the memorial meanings was anything but straightforward for Nantes city leaders. An argumentative struggle started as soon as the project was launched. Changing perspectives with respect to the ethics of public memory, and conflicting policy beliefs at the local level, challenged the initial justification narrative. At the core of the dispute was the decision of where to point the cursor between two ethical-emotional nexuses: one formed by the "indignation - recognition" couple, which dominated the decision to launch the project, and the other formed by the "local honor - anti-repentance" couple that emerged in the course of construction.

\section{Nantes' memorial to slavery: public art and meaning making}

Once the memorial project had been agreed, a process started to choose the artist and design of the monument. A select committee was put in place comprised of civil servants, art professionals, architects and representatives from the mobilized group. The deputy

\footnotetext{
${ }^{12}$ Interview with the deputy mayor in charge of the memorial project, May 2011.
} 
mayor in charge of arts and culture chaired the committee. At first, the scope of the project was restricted to providing the city with a permanent monument that could satisfy the demands of the Caribbean community and make the city appear to care about the issue. The budget, capped at 100,000 euros, fitted in with this modest ambition. A statue of the sort that had been destroyed had the Caribbean militants' favor. With its classical, but inspiring, symbolism of broken chains and arms raised to the sky, it readily evoked freedom and Black agency in the face of oppression. However, debates arose among the choice committee when it turned out that the process could also result in a more ambitious monument, one that would bear other, more complex, meanings, i.e. that Nantes as a community boldly "faced up" to its guilty past, and that the city was supportive of avantgarde art with an innovative culture policy in line with its strategical branding as a "cultural" city. In other words, there was also a territorial marketing dimension to the choice of the monument and this aspect was rapidly seen as crucial to various members of the jury, including the influential deputy mayor.

\section{Public art and territorial marketing rationale}

Of the various artwork concepts presented in response to the call for proposals, one was not a statue, but a memorial. Proposed by a renowned artist, Krzysztof Wodiczko ${ }^{13}$, this project was different from the other designs, which were mainly different versions of the liberated slave statue. Wodiczko's proposal (in collaboration with architect Julian Bonder) was an abstract, conceptual artwork, that proposed a disturbing sensorial experience of sad contemplation and conveyed intellectual interrogations about the nature of collective memory. It was also, for these reasons, much more in line with international

\footnotetext{
${ }^{13}$ Born into a Jewish family in Warsaw in 1943, Krzysztof Wodiczko, who later moved to the United States, is famous for his video projections on public monuments.
} 
contemporary memorial concepts. Although some members of the jury would have preferred sticking to the idea of a simple, expressive statue, members more versed in contemporary art (architects, director of the art school, civil servants from the art and culture department, the deputy mayor) pushed for Wodiczko's project. His concept killed two birds with one stone: it gave Nantes memory activists the permanent lieu de mémoire they wanted, but also singled out Nantes on the international map of contemporary memorials and architecture. Local pride would be satisfied. The director of Nantes School of Art, a member of the jury, conveyed the relevance of the latter aspect in his assessment of the concept:

\footnotetext{
"I've met Krzysztof Wodiczko on various occasions and I am convinced that he is a major artist of our time. His proposal is the only one that can attract attention nationally and even internationally. The monument would soon be known around the world. It's a blessing for Nantes to have received a proposal like this from an artist of this level. (...) These kinds of historical deeds [i.e. slavery] can only be turned into visual and sensorial experiences if they are subject to a creative, oblique, approach. Wodiczko's project is akin to the Holocaust Memorial in Washington, which has been the most visited monument in the last decades" (quoted in Chérel and Alvarez, 2012, 121).
}

Wodizko went on to win the competition. Yet this choice had a flip side. Taking a respected, international artist on board meant that he would take part in the meaningmaking process, applying his personal views about collective memory and the role of emotion: views that were not necessarily in line with city leaders' expectations.

\section{Wodiczko's memorial as an anti-monument}

Wodiczko designed a memorial that is not a direct evocation of the value of freedom, nor a tribute to the slaves' resistance. Rather, it encourages the visitor to "feel" the slave trade and meditate on it. The main part is a large tunnel that is literally dug into the Quai de la 
Fosse, right along the Loire River from which the visitor is only separated by the concrete structure of the old quay. On the other side of the tunnel, a glass inclined plane features shorts texts, such as excerpts from slave testimonies and legal texts about slavery and abolition. On the surface, a "meditation path" leads the visitor to the memorial's entrance. The path winds between hundreds of plaques set in the ground that feature the names of slave ships, trade posts on the African coast, and other evocations of the slave trade. The monument contains no graphic figuration of the slave trade or slavery. Rather, the uncomfortable passage through the dark, damp channel, with the river and ocean nearby, is designed to create a sensorial reminiscence of the slave trade, provoke meditation, and elicit emotions:

\begin{abstract}
"This place is rather gripping. It generates images and sensations. You can imagine the ship's departure, what the slaves endured, being locked in the hold of a ship... You are beneath the city, in a place that is hostile, very cold in winter, very clammy, and as you are in direct contact with the Loire, you can feel the wind, the waves slapping the dock... You are in an extremely rough place" ${ }^{14}$.
\end{abstract}

The concept of the Nantes memorial is inspired by the "counter-memory" approach (Young 1992; Stevens, Franck, and Fazakerley 2012), where monument designs are guided by reflexivity about the impossibility to "settle" a difficult past. The Second World War and the Jewish genocide were references for this trend of postmodern rewriting of memorials, in which victims, suffering and pain, take center stage, but are evoked through "anti-monumentality". Such monuments play with empathy and doubt rather than glory, pride and certitude. They are formed of suggestive symbols, and textural and sensorial environments, rather than dramatic scenery or statues. Their architecture does not seek elevation or verticality, but stays close to the ground, sometimes even going underground,

\footnotetext{
${ }^{14}$ Interview with a project manager, Nantes culture department, May 2011.
} 
and often relies on hollowness, horizontality and abstraction. At the cognitive level, these monuments do not seek to assert the grandeur of past deeds, as traditional monuments do, but rather to trigger introspection into the dark side of human societies and the unendingness of memory processes. The old ideals of glory, fame and triumph are thus replaced by the abstract figure of the victims, who are often represented by simple lists of names, stone blocks, or other unspectacular evocations. This symbolic presence of the victims also acts as a call to hear their voice in the present: Have the lessons been learned? Has justice been done?

Wodizcko's "anti-monument" memorial seeks to elicit feelings and emotions in a way that connects them to thought and beliefs. This emotion-cognition juncture draws a framework for the interpretation of public memorialization processes: the unendingness of memory, the unaddressed question of justice and accountability, the necessity of reflexivity. This conceptual framework expands beyond architecture. In order to materialize and raise awareness of the "debt" that Nantes owes to the victims of slavery, Wodiczko also proposed that a special tax should be levied on coffee sold in the city. Since Wodiczko's discursive and architectural "sensitization device" (Traïni 2009) is a city-sponsored and public-funded memorial, it raises questions about the capacity of policy makers to endorse such deconstructive, even subversive, views about "their" public memory process. While memory advocates from the Caribbean community were rather satisfied with the high profile of the chosen memorial, other policy actors were deeply unsettled. City leaders, in particular, perceived a troubling discrepancy between the meanings of the monument and their own vision of a pacified, straightforward, slavery memory. This led them to try to soften, and even contradict, the memorial's discourse. 


\section{Meanings struggles: keeping control of a policy narrative}

\section{Governing emotions}

Many Nantes officials and other policy actors were not prepared to conceive of the memory of slavery as a matter for moral introspection, nor to associate it with a disturbing reflection about evil and guilt. In fact, since the city had organized an exhibition about slavery in 1992-1994, the hegemonic narrative of the local policy of memory had emphasized the positive attitude of a city that had managed to "courageously" tackle an embarrassing issue. Emotional performativity therefore involved bravery, pride, and, notwithstanding the vagueness of the concept, the self-satisfaction of fulfilling the morally compelling "duty to remember". In contrast, doubts about the sense of memorialization, as conveyed by Wodizcko's Memorial concept, were not an issue. Somber emotions associated with the victims of the slave trade, the reminiscence of violence, feelings of guilt or the impossibility of justice were also kept in the shadows. In such a context, the artist triggered a resounding rupture in the policy narrative and provoked strong reactions. Critics readily targeted the emotional approach taken by the memorial's design. For instance, one reader of the local newspaper Ouest France criticized the "commiserating" perspective of this "American" monument in a letter to the editor:

"Wodizko takes us on an exuberant path on which he only reveals his lack of knowledge of the real history of the slave trade, and the local cultural, economic and administrative context. (...) The trend for compassionate meditation, which is overtaking every lieu de mémoire in the world, does for commemorations what McDonald's does for gastronomy. This very American concept (but directly inspired by Greek tragedy) pretends to liberate us through catharsis - 'we're made to cry, 
we're made to empathize.. and then we erase it all. 'I must confess I don't understand the choice of a foreign perspective so distant from our rationalist culture"15.

Critics like this one lamented the lack of historical content in the monument discourse. They would have favored a "cold-headed" approach to the past rather than a so-called "American" concept more prone to sensibility. Among the city council members, opposition parties also voiced disagreement. To them the monument tended to stigmatize Nantes, with its insistence on darkness, its hollowness, and its rough materials. The project "ran against the new dynamic image of Nantes by attaching the city to a past that is regrettable, but settled," deplored one city councilor ${ }^{16}$. Indeed, instead of this "gloomy monument buried underground"17, several councilors would have preferred a more visible, positive artwork that would reflect the city's pioneering attitude to coming to terms with its past, and the fact that "reconciliation had been achieved with the 'Shackles of Memory' exhibition" ${ }^{\prime 18}$.

These negative reactions to Wodiczko's design and ideas betrayed conflicting policy beliefs: was it really worth paying several million euros - the budget had steadily increased in the course of construction - to call international attention to Nantes' slavetrading past? Was it wise to favor an emotional approach centered on the gripping evocation of the suffering of slaves? In addition, for many policy actors, Wodiczko's memorial challenged the republican-inspired preference for "non-repentant" memory.

\footnotetext{
15 “Monument contre l'esclavage : le mauvais procès", Nantes-Forum, Ouest France, May 25, 2004.

${ }^{16}$ Minutes of Nantes city council, October 8, 2004. Municipal Archive.

17 "Le Mémorial échauffe toujours les esprits", Ouest France, February 15, 2008.

${ }^{18}$ Ibid.
} 
The artist's suggested tax on coffee is as a telling example: Was it not likely to stigmatize Nantais people as a community? Did it not amount to a form of reparation? The project was immediately rejected, even by supporters of the memorial, who deemed it a "typically Anglo-American" initiative that "didn't correspond to French republican sensibility"19. The memorial steering committee, composed of art professionals, city officials and members of the local memory advocacy movement, also promptly contested the idea, on the grounds that "the memorial shouldn't play on any sense of guilt, repentance or reparation." (Chérel and Alvarez 2012,97). Many of the participants in this sense-making battle wanted to let positive emotions take center stage rather than the "meditation" perspective favored by the artist, not to mention his guilt-inducing proposals. Indeed, a recurring accusation in the 2000s was that by endorsing Wodiczko's memorial the city had given in to a "repentant" attitude.

\section{The "anti-repentance" ethical trope}

At the time, "repentance" had become a formula commonly used in France to challenge any appeal to collective introspection, recognition of guilt, marked compassion for statecrime victims, or any moral attitude that could undermine national identity, especially with respect to the country's slavery and colonial past. This "repentance" narrative trope developed in conservative circles as a backlash to the "duty to remember" moral posture and to the resulting national policies of memory that acknowledged slavery crimes, most notably the "Taubira Law" of 2001, which recognized slavery and the slave trade as "crimes against humanity". Conservative sectors of the political and intellectual field reacted strongly to what they dubbed "a competition of victims". They held that yielding too much to colonial minorities could only result in undermining the national sentiment

\footnotetext{
${ }^{19}$ Interview with the deputy mayor in charge of the memorial, May 2011.
} 
and result in a fragmentation of identities along ethno-racial borders, something that would be at odds with the hardwired republican principle of not recognizing minorities. Just like its pendant "duty to remember" trope, the "anti-repentance" ethical trope associates emotion and ethics, i.e. a sense of pride and honor attached to national (or local) identity and adhesion to the morality of republicanism. This "national honor - antirepentance" nexus was very popular among the political right in the mid-2000s, but it was often also echoed by left-leaning politicians concerned that "republican" unity might indeed be at risk.

The strength of this national-level rhetoric affected Nantes, where it resonated deeply with local politicians unsettled by Wodiczko's approach, or challenged by the monument's critics: "It is not a question of blaming Nantes residents, nor pointing a finger at descendants of merchant families," the mayor and his team asserted on various occasions ${ }^{20}$. In order to convey a more positive message, the city council clarified the overall theme of the monument in 2004. Officially, the commemorative landmark is not dedicated to slavery or its victims, but to the abolition of slavery, which is of course more a source of pride and joy than regret and meditation. In press interviews and public speeches, sustained storytelling efforts were also made to ensure that positive emotions prevailed:

"We have a setting with these plaques installed on the ground [mentioning the names of slave trade ships $]^{21}$. But let me be clear that this is not a monument to the history

20 "Mémorial : 'Les vieux démons reviennent au galop”, Ouest France, February 16, 2008

${ }^{21}$ Originally, the artist wanted the plaques to mention the 4,000 ships that set sail from Nantes, the number of African slaves they embarked, and the number of deceased. The idea was abandoned because of cost restrictions. 
of the slave trade but indeed a monument to the abolition of slavery. So, obviously we have to consider slavery as a beginning, but the monument as a whole will be dedicated to its abolition: past abolition, present-day abolition struggles, and in the future as well (...). I've heard comments that there might be some repentance issues involved. I don't see, when we talk about Abbé Grégoire [a prominent abolitionist during the French Revolution, quoted on the monument] any link with repentance. No, it's a monument dedicated to abolitionism, that is to say, all those who fought, are still fighting, and continue to fight for that cause. ${ }^{22}$

Promotors of the monument were at pains to circumscribe the monument's meanings in a way that would ease its shame-inducing, or guilt-inducing, dimension. Architecture was also at stake. As mentioned above, there was a profound discomfort with the horizontal, hollow nature of the monument. As a response to this concern, the memorial's steering committee asked the artist to add a vertical element, for instance a lighthouse tower, to alleviate the extremely humble materiality of the place. In their view, a vertical addition of this kind would correspond better to the positive discourse about abolition and the "settled", proud nature of Nantes' relationship with the memory of the slave trade. The artist initially agreed to the idea... but it was nevertheless abandoned because of budget limitations.

\section{Conclusion}

“How does a policy mean?” Yanow famously asked (1996): it does so, to a large extent, through plotted narratives. While a very rich stream of works has demonstrated the necessity to pay close attention to the way policies are "storied", the role of emotions in such narratives has not been frequently assessed. To be sure, it is not uncommon in the narrative studies literature to suggest that "facts are as important as emotions in the

\footnotetext{
${ }^{22}$ Minutes of the city council, Nantes, October 8, $2004: 231-232$.
} 
construction of a problem and the identification of the target populations" (O'Bryan, Dunlop, and Radaelli 2014). Studies generally relate this emotional dimension to the rhetoric work of identifying "heroes" and "villains". But analyzes rarely go as far as analyzing how such emotions relate to specific beliefs: do storied emotions shape policy beliefs? are they shaped by beliefs?

The article argues that the possibility to enroll emotions into meaning-making operations is deeply structured by dominant ethical norms and constrained by power relations. In Nantes, powerful actors have strived to "correct" the affects associated with the memory problem and with Wodiczko's memorial in accordance with their ethical preference for a "non-repentant" approach of race-relations. Legitimate indignation at the fate of the slaves (and their descendants), a feeling encouraged by the militants' and the artist's sense-making efforts, collided with the local policy makers' structuring concern about not undermining collective honor. Consequently, political elites produced a counter narrative which challenged the delimitation between the "villains", "heroes" and "victims" of the story. Nantes white families finally became the one at risk of stigmatization ; slave-descendants represented a threat to collective identities... As a result, using their narrative and labelling power, Nantes elites managed to restrict references to violence, exploitation, pain, suffering, guilt or debt. Rather, they favored a more positive reading of the monument, which they associated with feelings such as local pride, courage, unity and joy.

While the case of a public memorial building may appear well adapted to a political study centered on the articulation between power, beliefs and emotional narratives, in my view, such an approach is not policy-field specific. Public discussions have been emotionally charged in a large number of policy domains (e.g. hijab bans, same-sex marriage, climate 
change, safe drug consumption, minority rights...). It would certainly be useful to understand better, in these various cases, the extent to which dominant ethics and power relations set (and restrict) the possibility to enroll emotional narratives in meaningmaking operations.

\section{References}

Ahmed, S. 2014. The Cultural Politics of Emotion. 2nd Revised ed. Edinburgh: Edinburgh University Press.

Ambroise-Rendu, A-C., and C. Delporte, eds. 2008. L'indignation : Histoire d'une émotion politique et morale, 19e-20e siècles. Paris: Nouveau Monde Editions.

Anderson, R. 2014. "Playing the Fool: Activists' Performances of Emotion in Policy Making Spaces." Emotion, Space and Society 13: 16-23. doi:10.1016/j.emospa.2014.05.004.

Anderson, R. 2016. "The Sentimental Civil Servant." In Emotional States: Sites and Spaces of Affective Governance, edited by E. Jupp, J. Pykett, and F. M. Smith, 8598. London: Routledge. doi:10.4324/9781315579252..

Ballet, M. 2014. Emotions et élections. Paris: INA Editions.

Barnes, M. 2008. "Passionate Participation: Emotional Experiences and Expressions in Deliberative Forums." Critical Social Policy 28 (4): 460-481. doi:10.1177/0261018308095280.

Beatty, A. 2014. "Anthropology and Emotion." Journal of the Royal Anthropological Institute 20 (3): 545-563. doi:10.1111/1467-9655.12114.

Blondiaux, L., and C. Traïni, eds. 2018. La Démocratie des émotions. Paris: Presses de Sciences Po.

Brader, T., G. Marcus, and K. Miller. 2011. "Emotion and Public Opinion" In Oxford Handbook of American Public Opinion and Media, edited by L. Jacobs and R. Y. Schapiro, 381-401. Oxford: Oxford University Press.

Braud, P. 1996. L'émotion en politique. Paris: Presses de Sciences Po.

Burlone, N., and Mévellec A. 2019. "Biting in Emotions." presented at the ICPP General

Conference, Montréal, June.

Chérel, E., and G. B. Alvarez. 2012. Le Mémorial de l'abolition de l'esclavage de Nantes : Enjeux et controverses. Rennes: Presses universitaires de Rennes.

Cohen, S. 2002. Folk Devils and Moral Panics: The Creation of the Mods and Rockers. London, New York: Routledge (1st Ed. 1972).

Cordell, C. 2017. "La Construction genrée des affects politiques entre action et passion." In La politique à l'épreuve des émotions, edited by A. Faure and E. Négrier, 231239. Rennes: Presses universitaires de Rennes.

Durnová, A. 2013. "Governing through Intimacy: Explaining Care Policies through 'Sharing a Meaning,." Critical Social Policy 33 (3): 494-513. doi:10.1177/0261018312468305.

Durnová, A., F. Fischer, and P. Zittoun. 2016. "Discursive Approaches to Public Policy: Politics, Argumentation, and Deliberation." In Contemporary Approaches to Public Policy: Theories, Controversies and Perspectives, edited by B. Guy Peters and P. 
Zittoun, 35-56. International Series on Public Policy. London: Palgrave Macmillan UK.

Durnová, A. 2019. Understanding Emotions in Post-Factual Politics: Negotiating Truth. London: Edward Elgar Publishing.

Durnová, A., and Hejzlarová E. 2018. "Framing Policy Designs through Contradictory Emotions: The Case of Czech Single Mothers." Public Policy and Administration 33 (4): 409-427. doi:10.1177/0952076717709524

Edelman, M. 1971. Politics as Symbolic Action: Mass Arousal and Quiescence. New York, NY: Academic Press.

Edelman, M. 1977. Political Language: Words that Succeed and Policies that Fail. New York, NY: Academic Press.

Elias, N. 2000. The Civilizing Process: Sociogenetic and Psychogenetic Investigations. 2nd ed. Oxford ; Malden, Mass: Wiley-Blackwell.

Fischer, F. 2003. Reframing Public Policy: Discursive Politics and Deliberative Practices. Oxford: Oxford University Press.

Fischer, F., and J. Forester, eds. 1993. The Argumentative Turn in Policy Analysis and Planning. Durham, NC: Duke University Press.

Garcés, M., and L. Finkel. 2019. "Emotional Theory of Rationality." Frontiers in Integrative Neuroscience 13. doi:10.3389/fnint.2019.00011.

Goodwin, J., J. M. Jasper, and F. Polletta, eds. 2001. Passionate Politics: Emotions and Social Movements. Chicago: University of Chicago Press.

Gottweis, H. 2012. "Political Rhetoric and Stem Cell Policy in the United States: Embodiments, Scenographics, and Emotions." In The Argumentative Turn Revisited: Public Policy as Communicative Practice, edited by F. Fischer and H. Gottweis, 211-235, Durham, NC: Duke University Press.

Gusfield, J. 1963. Symbolic Crusade. Status Politics and the American Temperance Movement. $2^{\text {nd }}$ ed. Chicago: University of Illinois Press.

Henry, E. 2015. Amiante : Un scandale improbable : Sociologie d'un problème public. Res publica. Rennes: Presses universitaires de Rennes.

Hourcade, R. 2012. "Commemorating a Guilty Past: The Politics of Memory in the French Former Slave Trade Cities." In Politics of Memory. Making Slavery Visible in the Public Space, edited by A. L. Araujo, 124-140. New York, NY: Routledge.

Hourcade, R. 2014. Les ports négriers face à leur histoire. Politiques de la mémoire à Nantes, Bordeaux et Liverpool. Paris: Dalloz.

Hourcade, R. 2017. A Tale of Two European Cities: Official Memories of Slavery and the Politics of Recognition in Liverpool and Nantes, Edited by A. Gueye and J. Michel, 211-230. Trenton (NJ): Africa World Press.

Jasper, J. M. 2011. "Emotions and Social Movements: Twenty Years of Theory and Research." Annual Review of Sociology 37 (1): 285-303. doi:10.1146/annurev-soc081309-150015.

Jasper, J. M. 2014. "Constructing Indignation: Anger Dynamics in Protest Movements." Emotion Review 6 (3): 208-213. doi:10.1177/1754073914522863.

Jones, M., E. Shanahan, and M. McBeth, eds. 2014. The Science of Stories: Applications of the Narrative Policy Framework in Public Policy Analysis. New York: Palgrave Macmillan US. doi:10.1057/9781137485861..

Kleres, J. 2011. "Emotions and Narrative Analysis: A Methodological Approach". Journal for the Theory of Social Behaviour 41 (2): 182-202 doi:10.1111/j.14685914.2010.00451.x 
Krieg-Planque, A. 2010. "Un lieu discursif : « Nous ne pourrons pas dire que nous ne savions pas ». Étude d'une mise en discours de la morale." Mots. Les langages $d u$ politique 92: 103-120. doi:10.4000/mots.19571.

Lamont, M. 2018. “Addressing Recognition Gaps: Destigmatization and the Reduction of Inequality." American Sociological Review 83 (3): 419-444. doi:10.1177/0003122418773775.

Le Bart, C. 2018. Les émotions du pouvoir: Larmes, rires, colères des politiques. Paris: Armand Colin.

Ledoux, S. 2012. "Le 'devoir de mémoire', fabrique du postcolonial ? Retour sur la genèse de la 'loi Taubira'." Cahiers d'histoire. Revue d'histoire critique 118: 117130.

Levi-Strauss, C. 1962. Totemism. London: Merin Press.

Marcus, G. 2002. The Sentimental Citizen: Emotion in Democratic Politics. Philadelphia: Pennsylvania State University Press.

Mercer, J. 2010. "Emotional Beliefs." International Organization 64 (1): 1-31. doi:10.1017/S0020818309990221.

Muramatsu, R., and Y. Hanoch. 2005. "Emotions as a Mechanism for Boundedly Rational Agents: The Fast and Frugal Way." Journal of Economic Psychology 26 (2): 201221. doi:10.1016/j.joep.2004.03.001.

Nussbaum, M. C. 2001. Upheavals of Thought: The Intelligence of Emotions. 1st ed. Cambridge ; New York: Cambridge University Press.

Nussbaum, Martha C. 2006. Hiding from Humanity. Disgust, Shame, and the Law. Princeton: Princeton University Press.

O'Bryan, T., C. A. Dunlop, and C. M. Radaelli. 2014. "Narrating the 'Arab Spring': Where Expertise Meets Heuristics in Legislative Hearings." In The Science of Stories: Applications of the Narrative Policy Framework in Public Policy Analysis, edited by M. Jones, E. Shanahan, and M. McBeth, 107-130. New York: Palgrave Macmillan US.

Ost, D. 2004. "Politics as the Mobilization of Anger: Emotions in Movements and in Power."European Journal of Social Theory 7 (2): 229-244. doi:10.1177/1368431004041753.

Paterson, S. 2019. "Emotional Labour: Exploring Emotional Policy Discourses of Pregnancy and Childbirth in Ontario, Canada." Public Policy and Administration 095207671986978. Epub ahead of print. doi:10.1177/0952076719869786.

Pickersgill, M. 2012. "The Co-Production of Science, Ethics, and Emotion." Science, Technology, \& Human Values 37 (6): 579-603. doi:10.1177/0162243911433057.

Polkinghorne, D. 1988. Narrative Knowing and the Human Sciences. Albany: State University of New York Press.

Polletta, F. 2006. It Was like a Fever. Storytelling in Protest and Politics. Chicago: University of Chicago Press.

Rein, M., and Schön D. 1993. "Reframing Policy Discourse." In The Argumentative Turn in Policy Analysis and Planning, edited by F. Fischer and J. Forester, 145-166, Durham, NC: Duke University Press.

Richards, B. 2007. Emotional Governance: Politics, Media, and Terror. New York (NY): Palgrave Macmillan.Roe, E. 1994. Narrative Policy Analysis: Theory and Practice. Durham: Duke University Press.

Russell, N. W., G. E. Marcus, A. N. Crigler, and M. Michael. 2007. The Affect Effect: Dynamics of Emotion in Political Thinking and Behavior. 1st ed. Chicago: University of Chicago Press. 
Schneider, A., and H. Ingram. 1993. "Social Construction of Target Populations: Implications for Politics and Policy." American Political Science Review 87 (2): 334-347. doi:10.2307/2939044.

Simon, H. A. 1983. Reason in Human Affairs. Stanford: Stanford University Press.

Stevens, Q., K. A. Franck, and R. Fazakerley. 2012. "Counter-Monuments: The AntiMonumental and the Dialogic." The Journal of Architecture 17 (6): 951-972. doi:10.1080/13602365.2012.746035.

Stone, D. 2012. Policy Paradox - The Art of Political Decision Making. 3rd ed. New York: W. W. Norton \& Company.

Traïni, C., ed. 2009. Emotions . . Mobilisation! Paris: Presses de Sciences Po.

Van Oorschot, K., M. Fenger, and M. Van Twist. 2016. "Choice Architecture as New Governance: The Case of the Dutch Housing Market." In Emotional States : Sites and Spaces of Affective Governance, edited by E. Jupp, J. Pykett, and F. M. Smith, 55-68. London; New York (NY): Routledge.

Vasilopoulos, P., G. E. Marcus, N. A. Valentino, and M. Foucault. 2019. "Fear, Anger, and Voting for the Far Right: Evidence from the November 13, 2015 Paris Terror Attacks." Political Psychology 40 (4): 679-704. doi:10.1111/pops.12513.

Wagenaar, H. 2011. Meaning in Action: Interpretation and Dialogue in Policy Analysis. New York (NY): Routledge.

Weber, M. 1971. Economie et Société. Paris: Plon.

Yanow, D. 1996. How Does a Policy Mean?: Interpreting Policy and Organizational Actions. Washington, DC: Georgetown University Press.

Young, J. 1992. "The Counter-Monument: Memory against Itself in Germany Today." Critical Inquiry 18 (2): 267-296. doi:10.1086/448632. 